\title{
ICT in education policy in Rwanda: current situation, challenges and prospects
}

\author{
Innocent Twagilimana (1) and Sirkku Mannikko-Barbutiu (2) \\ (1) University of Rwanda, College of Education. Postal Address: PO Box 5039, \\ Kigali, Rwanda. Tel.: +250787684457. E-mail: twagilin@gmail.com \\ (2) University of Stockholm, Sweden. Postal Address: Borgarfjordsgatan 12, Kista. Tel.: \\ +468161663. E-mail: Sirkku@dsv.su.se
}

\begin{abstract}
The purpose of this paper is to critically examine the policies of ICT in education in Rwanda in order to appreciate to what extent the intended policy goals and related operational plans are likely to lead to the expected results. The study draws on a number of policy documents and refers to a set of theoretical considerations to examine not only the status of the concerned policies but also the relevance of corollary operational plans. The analysis shows that clear and relevant policy goals and visions have been laid out, that they are accompanied with coherent strategies and plans but that the expected integration of ICT to support learning is yet to meet appropriate requirements. It is concluded that a shift in the typical design of the operational plans related to ICT is essential if a policy implementation that supports social and economic development is to be realised.
\end{abstract}

Key words: ICT policy, technology in education, innovative ICT projects, Rwanda

\section{Introduction}

Initiatives aimed at getting Information and Communication Technologies (ICTs) used in schools have become pervasive. In Africa, ICTs are being imported and visionary policy documents drafted with the hope of achieving more educational productivity and subsequent socio-economic transformation. The education sector has been often envisaged as a priority because it is expected to play a critical role in the accomplishment of the desired transformation.

Despite various descriptive reports about the existing policies and related programmes and plans, there seems to be a shortage of thorough studies about how the intended policy goals and visions are being transformed into practice and what has been the impact on the beneficiaries. A legitimate concern in this context actually relates to the possibility of developing and enacting strategies and plans likely to lead to the intended results.

According to research on the subject, national policies on ICT in education are developed to provide a rationale, a set of goals, and a vision for how education systems might be with the introduction of ICT, and how students, teachers, parents, and the general population might benefit from its use in schools [1]. In other words, the national policies can be regarded as a primary source of motivation for change as they set direction and play the role of harmoniser for potential disparate efforts. National

ACRID 2017, June 20-21, Victoria Falls, Zimbabwe

Copyright (C) 2017

DOI 10.4108/eai.20-6-2017.2270006 
policies are also supposed to have 'companion operational policies' that can set up programmes and provide resources that enable desired changes [1]. Strategic policies usually make more or less implicit suggestions about what facets will be emphasized throughout the enactment process. As indicated by empirical studies [2, 3], a typical procedure proposes aspects pertaining to establishment of the necessary technical infrastructure as the first main policy interest, often followed by a change in the curriculum for introducing aspects such as 'learning about ICT', and often in combination with organisation of in-service teacher training about the technical aspects of ICT. Interest in technical infrastructure will be followed by a phase proposing to integrate ICT in the different subject areas, as a kind of supplement to existing programmes. In-service teachers are trained about developing new pedagogy and subject teaching methods to make good use of the potential of ICT in the different subject areas.

As suggested in some studies [4] [2] [5], integrating technology into different subject areas requires prior adaptation or even change in the pedagogical and didactical approaches of those subject areas. In other words, the potential of ICT as a cognitive tool to support learning can only be effective when accompanied with pedagogical and curricular transformation. This scenario appears however contrary to how technology is typically envisaged where it is often expected to play a primary role in the process of transformation of education systems. This is probably the reason why the phase corresponding to integration of ICT in different subject areas does not seem to play out successfully in a number of educational contexts [3].

This paper is the first part of a larger research project that examines how university science teachers are operationalizing the policy intentions in their everyday curriculum practices. The current paper focuses on the particular case of Rwanda and has as purpose to examine the country's ICT policy goals and vision and the related implementation strategies and plans. It is guided by the following research questions:

- What is the status of the current ICT policy goals and visions in Rwanda?

- What are the strategic programmes and implementation plans that realise the existing policy?

- What are the main challenges encountered?

- What are the prospects likely to help achieve the desired results?

Apart from the introduction and conclusion, the paper is made of three main sections corresponding to the (i) description of the main ICT policy documents with a focus on policy goals and vision and related operational plans; (ii) analysis of challenges faced with in the implementation process, and (iii) prospects for achieving the desired results.

\section{Policy Goals and Vision and Related Programmes}

In Rwanda, a Sub-Saharan African country, the national ICT in education policy is part of a process of education reforms undertaken by the country since 1994. The year 1994, renowned for the genocide that devastated the country and killed more than one million people, actually marked the start of a new era characterised by a series of reforms in different sectors of the country including education. Reforms undertaken in the sector of education have been mainly underpinned by the concepts of "universal equitable access and quality education" provision where ICT was expected to serve as a critical leverage. Indeed, one of the general goals of the Rwandan educational sector policy 
emphasises the necessity "to encourage programmes and projects that will maximise the benefits ICT can bring in providing access and quality to education" [11]. Such an emphasis has transpired across various official documents since early 2000s with the launch of the national Vision 2020 whose main objective was to move Rwanda from an agriculture based economy to a knowledge-based society and a middle-income country by 2020 [6]. There is actually a strong alignment between the ICT in education policy, the national social and economic development goals and vision, and the different operational programmes, initiatives or plans as shown in the documents analysed and summarized below:

Table 1: Summary of analysed documents

\begin{tabular}{|c|c|c|c|}
\hline Policy document & Year & Main vision & $\begin{array}{l}\text { Concrete } r \text { goal(s) } \\
\text { vis-a-vis ICT in } \\
\text { education }\end{array}$ \\
\hline $\begin{array}{ll}\text { Rwanda } & \text { Vision } \\
2020 & \end{array}$ & 2000 & $\begin{array}{l}\text { Transformation 'from a } \\
\text { subsistence agricultural } \\
\text { economy to a knowledge- } \\
\text { based society, with a } \\
\text { vibrant class of } \\
\text { entrepreneurs' }\end{array}$ & $\begin{array}{ll}\text { Improve } & \text { ICT } \\
\text { infrastructure } & \end{array}$ \\
\hline $\begin{array}{l}\text { Economic } \\
\text { Development and } \\
\text { Poverty Reduction } \\
\text { Strategy }\end{array}$ & 2001 & $\begin{array}{l}\text { Development of required } \\
\text { skills for a knowledge- } \\
\text { based society; increasing } \\
\text { innovation in the ICT } \\
\text { industry; leveraging ICT } \\
\text { in education. }\end{array}$ & $\begin{array}{l}\text { Connection of all } \\
\text { schools; availing } \\
\text { technical support; } \\
\text { training teachers in } \\
\text { basic ICT skills; } \\
\text { initiating } \\
\text { professional } \\
\text { certification } \\
\text { courses. }\end{array}$ \\
\hline $\begin{array}{l}\text { National } \\
\text { Information and } \\
\text { Communication } \\
\text { Infrastructure } \\
\text { (NICI) Plans }\end{array}$ & 2000 & $\begin{array}{l}\text { Addressing Rwanda's } \\
\text { developmental challenges } \\
\text { in the information and } \\
\text { technology age, in order to } \\
\text { accelerate the country's } \\
\text { socio-economic } \\
\text { development. }\end{array}$ & $\begin{array}{l}\text { Transforming the } \\
\text { educational system } \\
\text { using ICTs to } \\
\text { improve } \\
\text { accessibility, } \\
\text { quality and } \\
\text { relevance. }\end{array}$ \\
\hline $\begin{array}{l}\text { Policy on Science, } \\
\text { Technology and } \\
\text { Innovation }\end{array}$ & 2006 & $\begin{array}{l}\text { Use and integration of } \\
\text { science, as well as } \\
\text { computer literacy that } \\
\text { shall be promoted and } \\
\text { popularised in schools and } \\
\text { in various work places. }\end{array}$ & $\begin{array}{l}\text { Promoting } \\
\text { publications, } \\
\text { studies, } \\
\text { investigations and } \\
\text { reports in the ICT } \\
\text { sector. }\end{array}$ \\
\hline $\begin{array}{lr}\text { Education } & \text { Sector } \\
\text { Strategic } & \text { Plan } \\
\text { (ESSP) 2013/14 - } \\
2017 / 18\end{array}$ & 2013 & $\begin{array}{l}\text { Promotion of full use of } \\
\text { ICT in education for } \\
\text { improvement of quality in }\end{array}$ & $\begin{array}{l}\text { Promoting and } \\
\text { supporting } \\
\text { integration of ICT in } \\
\text { education practices. }\end{array}$ \\
\hline
\end{tabular}




\begin{tabular}{|l|l|l|l|}
\hline & & $\begin{array}{l}\text { teaching, learning and } \\
\text { research. }\end{array}$ & \\
\hline $\begin{array}{l}\text { SMART Rwanda } \\
\text { Master Plan }\end{array}$ & 2015 & $\begin{array}{l}\text { Utilising ICT as "a tool to } \\
\text { enhance teaching and } \\
\text { learning" with a view to } \\
\text { achieve knowledge-based } \\
\text { economic developments. }\end{array}$ & $\begin{array}{l}\text { Providing more } \\
\text { educational } \\
\text { opportunities and } \\
\text { accessibilities by } \\
\text { developing ICT } \\
\text { skills }\end{array}$ \\
\hline $\begin{array}{l}\text { ICT in Education } \\
\text { Policy }\end{array}$ & 2015 & $\begin{array}{l}\text { Harnessing the innovative } \\
\text { and cost-effective } \\
\text { potential of world-class } \\
\text { educational technology } \\
\text { tools and resources, for } \\
\text { knowledge creation and } \\
\text { deepening (...). }\end{array}$ & $\begin{array}{l}\text { Development of a } \\
\text { relevant ICT } \\
\text { professional base; } \\
\text { increasing ICT } \\
\text { penetration and } \\
\text { usage; development } \\
\text { of education } \\
\text { leadership and } \\
\text { teachers capacity } \\
\text { through ICT; using } \\
\text { ICT to enhance } \\
\text { teaching, learning } \\
\text { and research in } \\
\text { HLIs. }\end{array}$ \\
& & &
\end{tabular}




\subsection{Rwanda vision 2020}

The Rwandan Vision 2020 is a result of a national consultative process that took place both at its inception between 1997 and 2000, and in 2012 when the Vision was revised. Vision 2020 was essentially aimed at transforming Rwanda "from a subsistence agricultural economy to a knowledge-based society, with a vibrant class of entrepreneurs" by 2020 [6]. Education is a key sector to this social and economic transformation, and the area pertaining to "science and technology, including ICT" features strongly among what has been described as cross cutting areas through which the Rwandan people aspirations of Vision 2020 will be realised. Regarding ambitions displayed to improve the sector of education, Vision 2020 recognises the nation's backwardness and shortages in the fields of applied and natural sciences and ICT. To this end, Vision 2020 expresses a strong commitment to improve ICT infrastructure based on options such as fiber optic network coverage all through the country, mobile telephone network coverage at $100 \%$, etc. Vision 2020 projects for example "to have internet access at all administrative levels, for all secondary schools and for a large number of primary schools" [6].

\subsection{Economic Development and Poverty Reduction Strategy II (EDPRS II)}

The Economic Development and Poverty Reduction Strategy (henceforth EDPRS II) appears as a more operationalised strategy of the vision 2020. According to the revised version of EDPRS II, "development of ICT capacity will be essential for reaching the Vision 2020 goal of transforming Rwanda into a knowledge-based economy" [7], as the ICT sector has a key cross-cutting role to play in supporting businesses, skills and public service delivery.

EDPRS II further emphasises the fact that skills development is a national priority and also a foundation for the achievement of NICI III as well as Vision 2020. Technology and ICT are thus pointed out in EDPRS II as one of the priority areas for improvement of productivity and youth employment. EDPRS II however recognises the existence of a "shortage both in terms of the quality and quantity of skilled personnel to drive ICT development as well as achieve Vision 2020 targets to develop required skills for a knowledge-based society" [7]. So, a complimentary area of focus is pointed out consisting in improving ICT professional skills and leveraging ICTs in education in order to accelerate skills development. As suggested by EDPRS II, "the scope of the skills development is twofold: first, build ICT professional skills that will increase innovation in the ICT industry and enable all sectors of the economy; and second, to leverage ICT in education", [7]. 
Regarding ICT use in schools, EDPRS II notes that the Rwandan Ministry of Youth and ICT (MYICT) will make sure that all schools are connected to ICT infrastructure, that technical support is available, and that teachers are trained in basic ICT skills. EDPRS II also suggests ICT professional certification courses to be "incorporated into the teaching curriculum at institutions of higher learning", [7].

\subsection{Education Sector Strategic Plan (ESSP) 2013/14 - 2017/18}

Presenting ICT as a central component of the science and technology education programme, ESSP 2013/14 - 2017/18 reaffirms the commitment of the education sector to promote ICT in education in the following terms [11]:

ICT in education will be promoted during the course of this ESSP by developing capacity of teaching staff to integrate the use of ICT into education practices via training on the use of ICT in teaching practice, development of ICT standards and competencies and provision of technical and pedagogical support in schools, developing and distributing quality digital content and ensuring that this content is adapted to the Rwandan context and aligned with the national curriculum and expanding Open, Distance and e-Learning (ODeL), principally through the newly established University of Rwanda.

As suggested in ESSP, full use of ICT is to be viewed as one of the critical factors for improvement of quality in teaching, learning and research.

The education sector strategy actually clearly reflects an existing commitment to improve performance in science and technology at all levels of education by enhancing teaching, facilities and learning materials, as well as by supporting research and application of science, technology and innovation in relevant sectors of the economy. Further, ESSP recognises the need to "roll out the appropriate use of ICT in teaching and learning", if the quality and supply of teaching and learning resources is to be ensured [11].

2.4 Policy on Science, Technology and Innovation, National Information and
Communication Infrastructure (NICI) Plans, and SMART Rwanda Master Plan

Policy on Science, Technology and Innovation relays the commitment to the national skills development expressed in Vision 2020 and EDPRS II as it advocates the use and integration of science, as well as computer literacy that shall be promoted and popularised in schools and in various work places [8]. Policy on Science, Technology and Innovation recommends not only intensification of training efforts (...) but also makes strongly the case of "publications, studies, investigations and reports in the ICT sector' [8]. 
With regard to the Rwandan National Information and Communication Infrastructure (NICI) Plans, they count as one of the Vision 2020 medium-term strategies, and are part of a process of five-year rolling plans that started in 2001 . These plans were meant to "address Rwanda's developmental challenges in the information and technology age, in order to accelerate the country's socio-economic development" [9]. NICI plans strive to create conducive environment for ICT development in various national sectors. Regarding education, the imperative of national skills development is strongly emphasised. NICI plans comprise among other objectives "to transform the educational system using ICTs with the aim of improving accessibility, quality and relevance for the development needs of Rwanda" [10]. Some of the achievements in the education sector are reported in NICI 2011-2015 [9]:

Numerous ICT in education initiatives including ICT training for teachers and 'One Laptop Per Child' initiative that are transforming the delivery and quality of education; Science and Technology scholarships that are growing the number of ICT capacity; Schoolnet that aims to improve connectivity and deploy ICT tools in 12-year basic education schools; RwEdNet that is interconnecting Rwanda's institutions of higher learning and linking them to global education and research networks, and the Rwanda Education Commons a one-stop portal for education information. These initiatives are transforming and improving the delivery and quality of education in Rwanda.

The need to improve skills development strongly highlighted in the above policy documents is also echoed in SMART Rwanda Master Plan 2016-2020 which reaffirms the existing commitment to provide more educational opportunities and accessibilities by developing ICT skills [10]. Indeed, education and training constitute one of the seven pillars underpinning the SMART Rwanda Master Plan [10]. As indicated by SMART Rwanda Master Plan 2016-2020, under the section entitled 'Strategic Planning', ICT will be utilized as "a tool to enhance teaching and learning" with a view to, inter alia, achieve knowledge-based economic developments (...) [10].

\subsection{ICT in Education Policy}

ICT in Education Policy appears as an attempt to operationalise the above described goals and visions in the education sector. ICT in Education Policy notes that technology can be used in education to address the key challenges of access, quality, equity, relevance and management and reiterates the opportunity of using ICT to address a number of existing challenges in the education sector. The latter include improvement of the quality of teaching by helping train new teachers, up-grading skills for unqualified teachers and increasing access to tertiary education. The policy also highlights the role of ICT in availing learning materials through the use of digital learning resources and suggests ICT to be used to strengthen teacher professional development and enable development of the $21^{\text {st }}$ century skills that are required for succeeding and thriving in today's complex, technology-based global economy. 
ICT in Education Policy presents its vision for ICT in Education emphasising the role of ICT as a learning tool designed to "harness the innovative and cost-effective potential of world-class educational technology tools and resources, for knowledge creation and deepening, to push out the boundaries of education (...)' [12].

Further, the need to improve skills development through ICT as mentioned in the policy documents described above is a bit more elaborated in the ICT Policy in Education document. ICT Policy in Education (as approved in 2016) presents strategic goals corresponding to four projects to be implemented for maximizing the benefits that ICT can bring to the national education system [12]. These goals can be summarised as follows:

- Development of a competent and relevant ICT professional base underpinned by clear and effective policies, adequate curriculum and content, and an effective Management and Information system;

- Increasing ICT penetration and usage at all educational levels based on a modern ICT infrastructure and relevant technology tools;

- Development of education leadership and teachers' capacity and capability in and through ICT;

- Enhancing teaching, learning and research through ICT integration in Higher Learning Institutions.

Judging by the above analysed documents, clear and relevant policy goals have been formulated and translated into coherent strategies and plans. This does not however guarantee successful integration of ICT to support learning as is suggested by empirical data obtained from reports conducted on the concerned policy goals and related strategic initiatives [13] [12] [14].

\section{Challenges Faced with in the Implementation of the Policy}

As suggested by UNESCO [14], effective ICT in education policies depend on, inter alia, three main pillars, namely access to ICT infrastructures and equipment, teacher capacities, and monitoring. Indeed, satisfactory realisation of these pillars is still faced with significant challenges in the context of Rwanda. On basis of data retrieved from various official reports, the preparation process of ICT in Education Policy [12] pointed out some major challenges likely to be encountered in the implementation of the above presented policy including inadequate infrastructure with $16 \%$ of electricity coverage in households by $2012,47 \%$ in public schools, low internet connectivity rate, lack of equipment and high costs, limited access to ICT in the education system (computer to students ratio in secondary schools is $40: 1$, while $16 \%$ of primary schools have access to laptops thanks to the One Laptop Per Child project). What was described as "the absence of a culture around the use of ICT" was also regarded as a hindrance to a widespread adoption of ICT in education. Issues related to the limited availability of digital content, as well as to expertise and project coordination were also pointed out. 
As noted in the concerned ICT in Education Policy, even when problems relating to equipment and cultural barriers are overcome and ICT in Education initiatives taken up, other challenges arise. The latter include limited availability of digital learning material, lack of expertise in project management and poor coordination of existing initiatives, technical support, etc. The problem of insufficient expertise is also emphasized by UNESCO stating that "Despite remarkable progress that has been made in higher education and capacity-building, evaluations of programmes still emphasize that capacity constraints are one of the most critical obstacles to programme implementation in the country'". UNESCO [14] also quotes data from the Rwandan Ministry of Public Service and Labour confirming that the skill shortage exists at all levels but is most acute at the technician cadre level where the deficit is $60 \%$ of the requirement.

The problem of information gaps has also been identified. It was found to be based on insufficient monitoring and evaluation of ICT in Education projects at school level, lack of analysis of the outcomes of partnerships, and on unclear standards in the sector [12].

\section{Existing Prospects}

As indicated in the above mentioned document of ICT in Education Policy, the latter was designed to "structure, catalyse, regulate and monitor initiatives on ICT in Education, in response to national development requirements, challenges and opportunities" [12]. Indeed, on observation of the current reality in the Rwandan education sector, strong commitment on the part of different educational stakeholders for support of ICT in Education initiatives is a good sign of hope for a rapid transformation of the sector. According to the findings of the Baseline Study conducted in 2016 on the Status of Open and Distance Learning in Rwanda [13], six projects were to be implemented for maximizing the benefits that ICT can bring to the national education system. These projects are:

- ICT Professional Certification Programmes: developing a competent and relevant ICT professional base;

- SchoolNet: Increasing of penetration and usage of ICT in 9 - and 12-year basic education

- $\quad$ ICT training for teachers: developing teacher capabilities in and through ICT

- Rwanda Education and Research Network (RwEdNet): enhancing teaching, learning and research through ICT in higher education

- $\quad$ Open, Distance and e-Learning (ODeL): increasing access to education

- Digital library: increasing access to scientific publications for educational institutions and the general public. 
In support of these projects, various opportunities to expand electricity and internet networks to schools across the country, research initiatives and an increasing awareness for the need to integrate ICT in the core curriculum, etc. are noticeable. Further, as transpired in a recent declaration made by the Rwandan Minister of Education during the opening ceremonies of a joint review meeting of the education sector performance in the 2014/15 fiscal year, the government of Rwanda still "believes in the use of ICT as a tool to strengthen education systems, knowledge dissemination, information access and more efficient service provision", and with this belief, "the ICT in Education Master Plan which is being developed will impact the delivery of education at all levels as it is aligned with Smart Rwanda". According to what was further stated by the Minister of Education, 'The Ministry of Education will prioritise ICT in the 2016/17 fiscal year budget in line with the implementation of the new competence-based curriculum to make Rwanda a knowledge-based economy by 2020' .

\section{Conclusion}

As shown throughout the above conducted review of different policy statements and strategic plans, the ICT sector in Rwanda has made considerable progress in policy and regulatory transformation by establishing a set of policy objectives and a trajectory leading to them. This process actually involved short and long-term plans with a series of strategies and programmes designed to help the system move forward. The process also strove to align the established programmes and plans with the national social and economic development goals and built on the country's limited resources to establish a series of rolling ICT Master Plans meant to realise the intended impact of the policy on the beneficiaries.

The implementation plans of the national ICT in Education Policy also provides modalities for improving the deployment of hardware in schools, ensuring professional capacities, and realising relevant institutional changes. In such a perspective, plans for future policies are implicitly laid down with a strong emphasis on the necessity for 'leveraging ICT in education' (EDPRS), 'developing computer literacy' and 'transforming the education system using ICT' (NICI Plans), 'utilising ICT as a tool to enhance learning' (SMART Rwanda), 'using ICT to enhance teaching, learning and research' (ICT in Education Policy), etc. 
The major challenge in this context remains to translate the emphasized technological leverage into improved classroom practices. Technical support and expertise that focus on changes in classroom practices that go beyond rote learning and foster deep understanding and, ultimately, knowledge creation and twenty-first century skills [14] are imperative because, as often indicated by research, having just a computer does not necessarily translate into meaningful learning outcomes. Teachers still need to develop capacity to take advantage of the tools available and the new teaching opportunities offered by ICT. As suggested in various studies reported by UNESCO [14], despite significant investments in hardware, software, networking, and all efforts deployed to ensure technical competences, effective utilisation of technologies in the classroom also depends on motivation and active involvement of teachers.

Therefore, if a policy implementation that supports social and economic development is to be realised, there is a need to envisage teacher professional development on ICT based on strong curricular and pedagogical purposes. In other words, a shift in the typical approach to designing the operational policies related to ICT is to be envisaged. This one would help focus technology integration efforts on educational purposes that technology enables and supports, rather than on the technology itself [4] as this seems to be suggested in the case of Rwandan operational ICT policies.

\section{References}

1. Kozma, R. B.: Comparative analysis of policies for education. In J. Voogt, \& G. Knezek (Eds.), International handbook of information technology in primary and secondary education, pp. 1083--1091. Berlin Heidelberg New York: Springer (2008).

2. Moonen, J.: Evolution of IT and related educational policies in international organizations. In J. Voogt, J., \&G. Knezek (Eds.). International Handbook of Information Technology in Primary and Secondary Education, pp.1071--1076. New York: Springer (2008).

3. Valcke, M., Rots, I., Verbeke, M., \& Van Braak, J.: ICT teacher training: Evaluation of the curriculum and training approach in Flanders. Teaching and Teacher Education (2007). Retrieved August 20, 2016, from Elsevier Science Direct at http://www.sciencedirect.com/science

4. Ertmer, P.A., \& Ottenbreit-Leftwich, A.: Removing obstacles to the pedagogical changes required by Jonassen's vision of authentic technology-enabled learning. Computers \& Education, 64, 175-182 (2012).

5. Jonassen, D. H., \& Reeves, T. C.: Learning with technology: using computers as cognitive tools. In D. H. Jonassen (Ed.), Handbook of research for educational communications and technology, pp. 693--719. Bloomington, In: Association for Communications and Technology (1996).

6. Republic of Rwanda: Rwanda Vision 2020 Revised 2012. Kigali (2012).

7. Ministry of Finance and Economic Planning (MINECOFIN). : Economic Development and Poverty Reduction Strategy II 2013-2018. Kigali: MINECOFIN (2013).

8. Ministry of Science, Technology and Scientific Research. : Policy on Science, Technology and Innovation. Kigali: the author (2006).

9. MINICT. : National Information and Communication Infrastructure (NICI) (2015). 
10. Republic of Rwanda. : SMART Rwanda Master Plan 2016-2020: Prosperous and Knowledgeable Society through SMART ICT. Kigali: MYICT (2016).

11. Ministry of Education: Education Sector Strategic Plan 2013/14 - 2017/18 (2013).

12. Ministry of Education: ICT in Education Policy (2015).

13. Mukama, E.: Baseline Study of the Status of Open and Distance Learning in Rwanda. Kigali: Mineduc (2016).

14. UNESCO. : Transforming Education: Power of ICT Policies. Paris: UNESCO (2011).

15. Hogarth, S, Bennett, J, Lubben, F, Campbell, B, \&Robinson, A.: ICT in Science Teaching: Technical Report. London: EPPI-Centre, Social Science Research Unit, Institute of Education, University of London (2006).

16. Voogt, J., \& Knezek, G.: International Handbook of Information Technology in Primary and Secondary Education. New York: Springer (2008). 